\title{
Sivas Yöresindeki Koyunlarda Schmallenberg Virus Enfeksiyonunun
}

\section{Seroprevalansının Belirlenmesi}

\author{
Adem ELMAS ${ }^{1}$, Öznur ASLAN ${ }^{2 *}$, Kezban Can ŞAHNA ${ }^{3}$ \\ ${ }^{1}$ Kangal îlçe Gıda Tarım ve Hayvancılık Müdürlüğü, Sivas, Türkiye. \\ ${ }^{2}$ Erciyes Üniversitesi, Veteriner Fakültesi, İç Hastalıkları Anabilim Dalı, Kayseri, Türkiye. \\ ${ }^{3}$ Fırat Üniversitesi, Veteriner Fakültesi, Viroloji Anabilim Dalı, Elazığ, Türkiye.
}

Geliş Tarihi: 08.02.2018

Kabul Tarihi: 26.05.2018

\begin{abstract}
Özet: Bu çalışmada, Sivas ilinde yetiştirilen Kangal Akkaraman ırkı koyun ve koçlarda Schmallenberg virus enfeksiyonunun seroprevalansının indirekt ELISA yöntemi ile ortaya konulması amaçlanmıştır. Bu amaçla; Sivas ilinde yetiştirilen Kangal Akkaraman ırkı, 1-4 yaş arasındaki toplam 368 adet (250 koyun, 118 koç) hayvandan kan örnekleri alınmıştır. Enfeksiyon, Schmallenberg virus'una spesifik antikorların tespit edildiği ELISA (IDEXX Schmallenberg Ab Test ${ }^{\circledR}$, IDEXX, Switzerland) yöntemi ile belirlenmiştir. Araştırmada, 368 hayvandan yalnızca 1 koyunda (\% 0.27) seropozitiflik tespit edilmiştir. Bilgilerimize göre sunulan çalışma, Sivas ilinde yetiştirilen ve ırk tescili yeni yapılmış Kangal Akkaraman ırkı koyunlarda Schmallenberg virusun varlığını bildiren ilk çalışmadır.
\end{abstract}

Anahtar Kelimeler: ELISA, Koyun, Schmallenberg virus, Seroprevalans.

\section{Seroprevalence of Schmallenberg Virus Infection in Sheep in Sivas Province}

Abstract: In this study, it was aimed to investigate the seroprevalence of Schmallenberg virus infection with indirect ELISA method in Kangal Akkaraman breed in Sivas, Turkey. For this purpose, blood samples of 368 Kangal Akkaraman sheep, consisting of 255 ewes and 118 rams, aged between 1 and 4 years old were collected. Seroprevalence of infection was detected with a commercial indirect ELISA kits (IDEXX Schmallenberg Ab Test ${ }^{\circledR}$, IDEXX, Switzerland) that were identified the presence of the Schmallenberg virus antibodies in serum samples. Only one animal was seropositive out of 368 animals $(0.27 \%)$. To the best of our knowledge, it's a novel report for presence of SBV infection in Kangal Akkaraman sheep, a breed whose first official herd book has only been established recently, in Sivas.

Keywords: ELISA, Sheep, Schmallenberg virus, Seroprevalence.

\section{Giriş}

Schmallenberg virus (SBV) enfeksiyonu, ilk kez Avrupa'da ruminantlarda saptanmış olup, Culicoides sp.'ndeki sokucu ve kan emici sinekler tarafından nakledilen enfeksiyöz bir hastalıktır (Pawaiya ve ark., 2013; Tuncer ve Yeşilbağ, 2012). Hastalık sığırlarda; ateş, iştahsızlık, süt veriminde azalma, kondüsyon kaybı, abort ve arthrogryposishydranencephaly sendromlu buzağı doğumu, koyun ve keçilerde ise konjenital malformasyonlara bağı ölü doğumlar ile karakterizedir (Doceul ve ark., 2013; Pawaiya ve ark., 2013). Schmallenberg virus, zarflı, 3 segmentli ve tek zincir RNA'ya sahip bir virustur. ilk pozitif örnek Almanya'nın "Schmallenberg" kasabasında belirlendiği için bu ismi almıştır (Hoffmann ve ark., 2011; Hoffmann ve ark 2013; Pawaiya ve ark., 2013). Filogenetik analizler SBV'un, Peribunyaviridae ailesinde (Kuhn ve ark., 2017), Orthobunyavirus genusunda yer aldığını göstermiştir (Doceul ve ark., 2013; Pawaiya ve ark., 2013; Tuncer ve Yeşilbağ, 2012). Bugüne kadar sığır, koyun, keçi ve bizonlarda enfeksiyonun varlığı tespit edilmiştir. Ayrıca alageyik ve karacalarda antikor varlığı saptanmış olması bu hayvanların doğal enfeksiyona maruz kalmış olabileceğini düşündürmüştür. Simbu serogrubunda yer alan virusların geniş bir konakçı spektrumuna sahip olduğu değerlendirildiğinde, önümüzdeki yıllarda Schmallenberg virusuna duyarlı birçok hayvan türünün belirlenmesi olasıdır. Örneğin; Akabane virusu ruminantlar dışında at, eşek, domuz gibi hayvanları da enfekte edebilirken, Simbu serogrubundaki bazı virusların kanatı hayvanlarda enfeksiyon oluşturabildiği ve deneysel olarak kemirgenleri enfekte edebildiği de bildirilmiştir (Tuncer ve Yeşilbağ, 2012).

SBV enfeksiyonu sokucu sinekler vektör aracılığıyla, özellikle de Culicoides türü sinekler ve sivrisineklerle bulaşır (Conraths ve ark., 2013; Pawaiya ve ark., 2013, Wernike ve ark., 2014). C. obsoletus complex, C. dewulfi ve $C$. chiopterus, $C$. dewulfi, C. pulicaris SBV açısından pozitif bulunmuş ancak sivrisinek ve kene gibi diğer artropodların taşıyıcılığına dair çalışmaya rastlanmamıştır (Doceul ve ark., 2013; Pawaiya ve ark., 2013). Boğa 
spermalarında SBV nükleik asidinin varlığı PCR ile gösterilmiş (Pawaiya ve ark., 2013) ve dişilere bulaşmada rol oynayabileceği ileri sürülmüştür (Hoffmann ve ark., 2013). Schmallenberg virusu şimdiye kadar Avrupa kıtasında bildirilmiştir. Öncelikle Almanya ve Hollanda'da başlayan vakaların daha sonraki dönemlerde, kuzeyde İngiltere'den İskoçya'ya kadar, Norveç'ten Finlandiya'ya, İsveç'ten İskandinavya bölgesine kadar yayıldığı bildirilmiştir. Ayrıca Estonya, Letonya, Macaristan ve Hırvatistan gibi doğu Avrupa bölgelerine yayılmıştır (Doceul ve ark., 2013; Tuncer ve Yeşilbağ, 2012). Avusturya'da 2012-2013 yıllarında yapılan taramalarda sığır (>\% 98), küçük ruminant (\% 58.3-95.6) ve vahşi ruminatlarda SBV enfeksiyonuna dair pozitiflik bildirilmiştir (Steinrigl ve ark., 2014). Türkiye'de yapılan çalışmalarda, Afyonkarahisar'da mandalarda, Adıyaman, Diyarbakır, Elazığ, Erzurum ve Sivas'da sığırlarda, Samsun ve Sinop'ta sığır, koyun ve keçilerde SBV seropozitifliği bildirilmiştir (Azkur ve ark., 2013). Ayrıca, patolojik örneklerde Rt-PCR yöntemiyle yapılan incelemelerde Lüleburgaz, Kırklareli ve Gelibolu'da SBV varlığı bildirilmiştir (Yılmaz ve ark., 2014). SBV enfeksiyonunda etkilenen genç hayvan sayısı ve enfekte dişi hayvan sayısına bağlı olarak üretim ve ekonomi etkilenir. Eğer dişilerde erken embriyonik dönemde enfeksiyon oluşursa, erken embriyonik ölüm oluşacağından hayvan tekrar kızgınlık gösterip gebe kalabilir ve böylece çok fazla bir ekonomik kayıp oluşmayabilir (Lievaart-Peterson ve ark., 2012). Belçika'da SBV'nin ekonomik önemini değerlendirmek için yapılan saha çalışmalarında ortalama maliyet her bir hayvan için 40 ile 200 Euro olarak hesaplanmıştır (Martinelle ve ark., 2014).

Çalışmanın amacı, Sivas ilinde yetiştirilen Kangal Akkaraman ırkı koyun ve koçlarda Schmallenberg virus enfeksiyonunun indirekt Enzyme-linked ImmunoSorbent Assay (ELISA) yöntemi ile seroprevalansının ortaya konulmasıdır. Schmallenberg virus ilk kez Avrupa' da 2011 yıllarında tanısı konulmuş yeni bir viral etken olup, Türkiye'deki yaygınlığı ile ilgili sınırlı sayıda çalışma bulunmaktadır. Sunulan çalışma ile daha önce Sivas bölgesinde sığırlarda belirlenmiş olan virusun varlığının koyunlarda olup olmadığının belirlenmesi ve epidemiyolojik açıdan veri oluşmasına katkı sağlanması amaçlanmıştır.

\section{Materyal ve Metot}

Hayvan Materyali: Çalışma materyali olarak, Sivas ilinde yetiştirilen Kangal Akkaraman ırkı, 27 farklı sürüden, 1-4 yaş arasındaki toplam 368 adet hayvandan (250 koyun, 118 koç) alınan kan örnekleri kullanıldı (Şekil 1.). Kan örnekleri 2015 Ocak ve Şubat ayı ile 2016 Kasım aylarında toplandı (Tablo 1.).

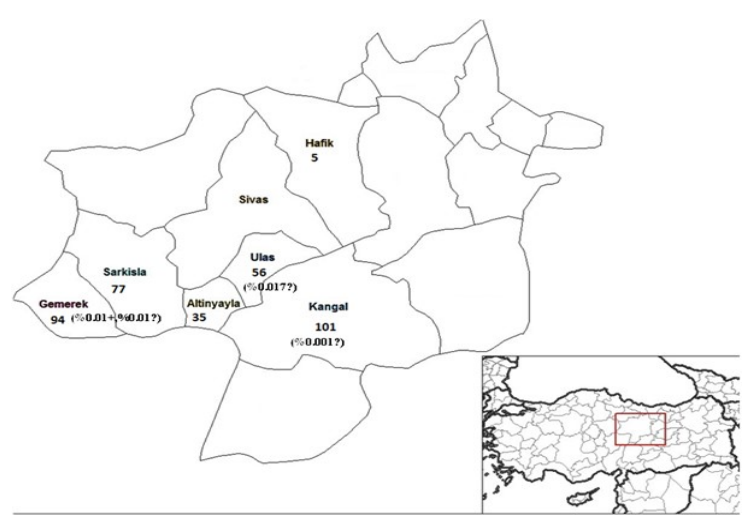

Şekil 1. Çalışmaya dahil edilen ilçeler ve ilçelerdeki numune dağııımı ile SBV seropozitif ve şüpheli hayvanların oranı.

Tablo 1. Sivas'ın numune alınan ilçeleri ve sürü sayıları.

\begin{tabular}{lc}
\hline İlçe & Sürü \\
\hline Altınyayla & 7 \\
Gemerek & 4 \\
Kangal & 8 \\
Şarkışla & 6 \\
Ulaş & 1 \\
Hafik & 1 \\
\hline
\end{tabular}

Kan Örneklerinin Alınması: Tüm hayvanların Vena jugularis'inden $10 \mathrm{ml}$ serum tüplerine kan örnekleri alındı. Örnekler 3000 devirde 15 dk santrifüj edilerek serumlar ayrıldı ve analizler yapılıncaya kadar -20 o C'lik derin dondurucuda saklandı.

Çalışma, Erciyes Üniversitesi Hayvan Deneyleri Yerel Etik Kurulu'nun 13.05.2015 tarihli ve 15/18 numaralı etik kurul kararı ile onaylandı.

Indirekt ELISA: Schmallenberg virusuna spesifik antikorlar ticari bir ELISA kiti (IDEXX Schmallenberg Ab Test ${ }^{\circledR}$, IDEXX, Switzerland) kullanılarak belirlendi.

\section{Bulgular}

Çalışmaya dahil edilen hayvanlardan 250 (\% 67.9) dişi ve 118 (\%32.1) erkek hayvandan örneklenen serumların yalnızca birinde (\% 0.27 ) Schmallenberg virus spesifik antikor varlığı saptandı. Üç koyunda ise test sonucu şüpheli antikor pozitiflik belirlendi. SBV antikor pozitif ve 2 şüpheli antikor pozitif hayvan dişi, 1 şüpheli antikor pozitif hayvan ise erkekti. Sivas ilinde yapılan çalışmada 
Schmallenberg virus seropozitiflik dağılımı Şekil 1.'de gösterildi.

\section{Tartışma ve Sonuç}

SBV varlığına ilişkin ilk bildirim kuzeybatı Almanya ve Hollanda'nın doğu bölgesinde yetişkin süt sığırlarında ortaya konulmuştur (Hoffmann ve ark., 2012). Avusturya'da 2012-2013 yıllarında yaptıkları taramalarda sığır (>\% 98), küçük ruminant (\% 58.3-95.6) ve vahşi ruminatlarda SBV açısından pozitiflik bildirilmiştir (Steinrigl ve ark., 2014). Belçika' da 2012 yılı Şubat-Nisan aylarında sığırların \% 91'inde SBV'una karşı antikor olduğu belirlenmiştir (Garigliany ve ark., 2012). Belçika'da Kasım 2011 ve Nisan 2012 arasında 83 sürüden toplanan 1082 koyunda seroprevalans \% 98.03 olarak belirlenmiştir (Meroc ve ark., 2014). Fransa'nın doğu ve kuzey bölgelerinde sığır ve koyunlarda yapılan seroprevalans çalışmalarında \%36-100 arasında değişen oranlar görülmüştür (Doceul ve ark., 2013). Afrika'da Mozambik'te yapılan seroprevalans çalışmasında her bir sürüde çalışmaya alınan sığırların \% 100, koyunların \% 43 97 ve keçilerin \% 72-100 oranında SBV pozitif olduğu bildirilmiştir (Blomström ve ark., 2014). Johnson ve ark. (2014), Güneybatı İrlanda'da SBV' nin yaygınlığını belirlemek üzere süt tanklarında örnekler almışlar ve 72 örnekten 9'unun pozitif 1 tanesinin şüpheli seropozitif olduğunu belirlemişlerdir. Balmer ve ark. (2014) İsviçre'de SBV'ye karşı oluşan antikor varlığını araştırdıkları çalışmada 2012 yılının Temmuz ayında 224 süt ineğinin ve Aralık ayında 211 süt ineğinden topladıkları süt örneklerinde sırasıyla \% 19.7 ve \% 99.5 oranında seropozitiflik tespit etmişlerdir. Türkiye' de Azkur ve ark. (2013) sığırlarda SBV seroprevalansını \% 39.8, koyunlarda \% 1.6, keçilerde \% 2.5 ve mandalarda \% 1.5 olarak bildirmişlerdir. Macun ve ark. (2017), Kırıkkale'deki koyunlarda yaptıkları çalışmada, seroprevalansını \%0.38 olarak bildirmişlerdir. Macun ve ark. (2017)'nın sonuçlarına benzer şekilde, bu çalışmada, Sivas ilindeki Akkaraman ırkı koyunlarda SBV seroprevalansının ( $\%$ 0.27) düşük olduğu belirlenmiştir. Türkiye'de SBV enfeksiyonuna dair sahada vaka bildiriminin az olması SBV akut enfeksiyonunun klinik bulgusunun tipik olmaması ve çiftçilerin bu enfeksiyonu belirleyememesi olabilir. Bu çalışmadaki düşük prevalans oranının, Sivas ilinin sert karasal iklime sahip olması nedeniyle enfeksiyonu nakleden, özellikle Culicoides sp. Türü kan emen sokucu sinek yoğunluğunun az oluşu ile ilgili olduğu düşünülmektedir. Ayrıca SBV enfeksiyonunu takiben yaklaşık 12 ile 14 gün arasında antikor oluştuğu ve SBV ile doğal enfekte yetişkin sığırlarda oluşan spesifik antikorun serumda varlığının en az 2 yıl devam etiği belirlenmiştir (Conraths ve ark., 2013; Elbers ve ark., 2014). Koyunlarda SBV ile doğal enfeksiyonda oluşan antikorların kalıcılığı ile ilgili literatüre rastlanamamış olmakla birlikte, bu çalışmada SBV pozitif seroprevalansın düşük olması ve üç şüpheli seropozitif örneğin olması zaman içerisinde mevcut antikorların titresindeki azalma ile açıklanabilir.

Sonuç olarak; Sivas ilinde Akkaraman ırkı koyunlarda SBV enfeksiyonunun düşük seroprevalans oranına sahip olduğu belirlenmiştir. SBV enfeksiyonu yönünde Sivas ilinde gelecekte yapılacak büyük ölçekli epidemiyololojik çalışmalar ve enfeksiyonunun naklinde rol oynayan vektörlerin varlığı/dağıımının araştırılması mücadeleye katkı sağlayacaktır. Ayrıca, bu veriler kullanılarak ileride oluşabilecek endemilerin önlenmesi amacıyla enfeksiyon yönetim, denetim ve araştırma şemaları da oluşturulabilir.

\section{Teşekkür}

Bu çalışma Erciyes Üniversitesi Araştırma Fonu tarafından TYL-15-6119 numaralı proje ile desteklenmiştir.

\section{Kaynaklar}

Azkur AK, Albayrak H, Risvanli A, Pestil Z, Ozan E, Yılmaz O, Tonbak S, Cavunt A, Kadı H, Macun HC, Acar D, Özenç E, Alparslan S, Bulut H, 2013: Antibodies to Schmallenberg virus in domestic livestock in Turkey. Trop Anim Health Prod, 45, 1825-1828.

Balmer S, Vögtlin A, Thür B, Büchi M, Abril C, Houmard M, Danuser J, Schwermer H, 2014: Serosurveillance of Schmallenberg virus in Switzerland using bulk tank milk samples. Prev Vet Med, 116(4), 370-379.

Blomström AL, Stenberg H, Scharin I, Figueiredo J, Nhambirre O, Abilio AP, Fafetine J, Berg M, 2014: Serological screening Suggests presence of schmallenberg virus in cattle, sheep and goat in the Zambezia province, Mozambique. Transbound Emerg Dis, 61(4), 289-292.

Conraths FJ, Peters M, Beer M, 2013: Schmallenberg virus, a novel orthobunyavirus infection in ruminants in Europe: Potential global impact and preventive measures. N Z Vet J, 61(2), 63-67.

Doceul V, Lara E, Sailleau C, Belbis G, Richardson J, Bréard $E$, Viarouge $C$, Dominguez $M$, Hendrikx $P$, Calavas $D$, Desprat A, Languille J, Comtet L, Pourquier $P$, Eléouët JF, Delmas $B$, Marianneau $P$, Vitour D, Zientara S, 2013: Epidemiology, molecular 
virology and diagnostics of Schmallenberg virus, an emerging orthobunyavirus in Europe. Vet Res, 44(1), 31.

Elbers AR, Stockhofe-Zurwieden N, van der Poel WH, 2014: Schmallenberg virus antibody persistence in adult cattle after natural infection and decay of maternal antibodies in calves. BMC Vet Res, 10, 103.

European Food Safety Authority, 2014: Schmallenberg virus: State of Art. EFSA Journal, 12(5), 3681.

Fernández-Aguilar $\mathrm{X}$, Pujols J, Velarde R, Rosell R, LópezOlvera JR, Marco I, Pumarola M, Segalés J, Lavín S, Cabezón O, 2014: Schmallenberg Virus circulation in high mountain ecosystems, Spain. Emerg Infect Dis, 20(6), 1062-1064.

Garigliany MM, Bayrou C, Kleijnen D, Cassart D, Desmecht D, 2012: Schmallenberg virus in domestic cattle, Belgium, 2012. Emerg Infect Dis, 18, 1512-1514.

Hoffmann B, Scheuch $M$, Hoper D, Jungblut R, Holsteg $M$, Schirrmeier $\quad H$, Eschbaumer $\quad M$, Goller KV, Wernike $\quad K$, Fischer $\quad M$, Breithaupt A, Mettenleiter TC, Beer M, 2012: Novel Orthobunyavirus in cattle, Europe, 2011. Emerg Inf Dis, 18, 469-472.

Hoffmann B, Schulz C, Beer M, 2013: First detection of Schmallenberg virus RNA in bovine semen, Germany, 2012. Vet Microbiol, 167(3-4), 289-95.

Johnson A, Bradshaw B, Boland C, Ross P, 2014: A bulk milk tank study to detect evidence of spread of Schmallenberg virus infection in the south-west of Ireland in 2013. Ir Vet J, 67(1), 11.

Kuhn JH, Maes $P$, Alkhovskiy $S$, Beer $M$, Briese $T$, Buchmeier M,Calisher C, Charrel R, Choi I, Clegg SC, De la Torre J, DeRisi L, Digiaro M, Ebihara $H_{\text {, }}$ Emonet S, Elbeaino T, Gonzalez JP, Haenni AL, Jain R, Zhou X, 2017: Taxonomic expansion and reorganization of the order Bunyavirales. ICTV [International Committee for Taxonomy of Viruses] Proposal (Taxoprop) No. 2017.012M.

Lievaart-Peterson K, Luttikholt SJM, Van den BromR, Vellema P, 2012: Schmallenberg virus infection in small ruminants- first review of the situation and prospects in Northern Europe. Small Rumin Res, 106, 71-76.
Macun HC, Azkur AK, Kalender H, Erat S, 2017: Kırıkkale'de yetiştirilen koyunlarda Schmallenberg virüs seroprevalansı ve bazı coğrafi özelliklerle ilişkisi. Ankara Üniv Vet Fak Derg, 64, 93-97.

Martinelle L, Dal Pozzo F, Gauthier B, Kirschvink $N$, Saegerman C, 2014: Field veterinary survey on clinical and economic impact of Schmallenberg virus in Belgium. Transbound Emerg Dis, 61(3), 285-288.

Meroc E, De Regge N, Riocreux F, Caij AB, van den Berg T, van der Stede Y, 2014: Distribution of Schmallenberg virus and seroprevalence in Belgian sheep and goats. Transbound Emerg Dis, 61(5), 425431.

Pawaiya RSV, Gupta VK, 2013: A review on Schmallenberg virus infection: A newly emerging disease of cattle, sheep and goats. Vet Med, 8(10), 516-526.

Steinrigl A, Schiefer P, Schleicher C, Peinhopf W, Wodak E, Bagó Z, Schmoll F, 2014: Rapid spread and association of Schmallenberg virus with ruminant abortions and foetal death in Austria in 2012/2013. Prev Vet Med, 116(4), 350-359.

Tuncer P, Yeşilbağ K, 2012: Schmallenberg virus: Ruminantlarda görülen yeni bir hastalık etkeni. Uludag Univ J Fac Vet Med, 1, 63-71.

Wernike K, Conraths F, Zanella G, Granzow H, Gache $K$, Schirrmeier H, Valas S, Staubach C, Marianneau $P$, Kraatz F, Höreth-Böntgen D, Reimann I, Zientara S, Beer M, 2014: Schmallenberg virustwo years of experiences. Prev Vet Med, 116(4), 423-34.

Yilmaz H, Hoffmann $\quad B$, Turan $\quad N$, Cizmecigil UY, Richt JA, Van der Poel WH, 2014: Detection and partial sequencing of Schmallenberg virus in cattle and sheep in Turkey. Vector Borne Zoonotic Dis, 14(3), 223-225.

*Yazışma Adresi: Öznur ASLAN

Erciyes Üniversitesi, Veteriner Fakültesi, İç Hastalıkları Anabilim Dalı, Kayseri, Türkiye.

e-mail: oznuratalay@gmail.com 